PHARMACONJurnal Ilmiah Farmasi - UNSRAT Vol. 9 No. 1 FEBRUARI 2020 ISSN 2302 - 2493

\title{
FORMULASI DAN UJI EFEKTIVITAS ANTIBAKTERI SEDIAAN SABUN CAIR EKSTRAK ETANOL DAUN KERSEN (Muntingia Calabura L.) TERHADAP BAKTERI Staphlococcous epidermidis
}

\author{
Freisy C.C Korompis ${ }^{1)}$, Paulina V.Y Yamlean ${ }^{1)}$, Widya Astuty Lolo ${ }^{1)}$ \\ ${ }^{1)}$ Program Studi Farmasi FMIPA UNSRAT Manado, 95115
}

\begin{abstract}
Cherry plants (Muntingia calabura L.) is a plant that has many properties in the treatment. One part of the plant that is widely used is the leaf which contain of flavonoid compounds, saponins and tannins contained in cherry leaves can inhibit bacterial activity. This study aims to formulate the liquid soap from ethanol extract of cherry leaves and test the antibacterial effectiveness of the liquid soap ethanol extract of cherry leaves with a concentration of $10 \%, 15 \%$ and $20 \%$ on the growth of Staphylococcus epidermidis bacteria. Liquid soap formulation of ethanol extract of cherry leaves with a concentration of $10 \%, 15 \%$ and $20 \%$ was conducted by laboratory experimental research. The results of testing the quality of liquid soap at a concentration of $10 \%$ meet the requirements according to the standards set by SNI namely organoleptic test, $\mathrm{pH}$, high foam, moisture content, free alkali content, specific gravity. Concentrations of $15 \%$ and $20 \%$ did not meet the requirements for specific gravity testing. The test results of the antibacterial effectiveness of liquid soap ethanol extract of cherry leaves using the diffusion method with way of wells can inhibit the bacteria Staphylococcus epidermidis at concentrations of $10 \%, 15 \%$, and $20 \%$ which categorize as weak.
\end{abstract}

Keywords: Kersen, Peel-off mask, Antibacterial, Staphlococcous epidermidis

\begin{abstract}
ABSTRAK
Tanaman Kersen (Muntingia calabura L.) merupakan tanaman yang memiliki banyak khasiat dalam pengobatan. Salah satu bagian tanaman yang banyak digunakan ialah bagian daun yang mengandung senyawa flavonoid, saponin dan tannin yang terdapat pada daun kersen mampu menghambat aktivitas bakteri. Penelitian ini bertujuan untuk memformulasi sediaan sabun cair ekstrak etanol daun kersen dan menguji efektivitas antibakteri sediaan sabun cair ekstrak etanol daun kersen dengan konsentrasi 10\%, 15\% dan 20\% terhadap pertumbuhan bakteri Staphylococcus Epidermidis. Formulasi sabun cair ekstrak etanol daun kersen dengan konsentrasi 10\%, 15\% dan 20\% dilakukan penelitian dengan metode eksperimental laboratorium. Hasil pengujian mutu sabun cair pada konsentrasi $10 \%$ memenuhi persyaratan sesuai standar yang ditetapkan SNI yaitu uji organoleptik, $\mathrm{pH}$, tinggi busa, kadar air, kadar alkali bebas, bobot jenis. Konsentrasi 15\% dan 20\% tidak memenuhi persyaratan pada pengujian bobot jenis. Hasil uji efektivitas antibakteri sabun cair ekstrak etanol daun kersen menggunakan metode difusi agar dengan cara sumuran dapat menghambat bakteri Staphylococcus Epidermidis pada konsentrasi $10 \%, 15 \%$, dan $20 \%$ yang termasuk dalam kategori lemah.
\end{abstract}

Kata kunci : Kersen, Masker peel-off, Antibakteri, Staphlococcous epidermidis 
PHARMACONJurnal Ilmiah Farmasi - UNSRAT Vol. 9 No. 1 FEBRUARI 2020 ISSN 2302 - 2493

\section{PENDAHULUAN}

Infeksi kulit masih menjadi suatu masalah kesehatan yang dihadapi masyarakat di negara berkembang termasuk Indonesia. Kulit (kutis) merupakan pembungkus dan pelindung tubuh yang tahan air, mengandung ujung-ujung saraf, dan membantu mengatur suhu tubuh (Gardner et al., 1995).

Antibakteri merupakan zat yang dapat mengganggu pertumbuhan atau bahkan mematikan bakteri dengan cara mengganggu metabolisme mikroba yang merugikan. Mekanisme kerja dari senyawa antibakteri diantaranya yaitu menghambat sintesis dinding sel, menghambat keutuhan permeabilitas dinding sel bakteri, menghambat kerja enzim dan menghambat sintesis asam nukleat dan protein (Dwidjoseputro, 1978).

Salah satu tanaman yang memiliki potensi untuk dikembangkan sebagai obat tradisional adalah daun Kersen (Muntingia calabura L.). Kersen merupakan tanaman yang banyak dijumpai di daerah tropis, antara lain adalah Indonesia, Philipina dan Meksiko tanaman ini banyak ditemui dipinggir selokan dan retakan dinding(Steenis et al., 1967). Aktivitas antibakteri daun Kersen ini disebabkan oleh adanya kandungan senyawa tanin, flavonoid, dan saponin yang dimilikinya, daun Kersen memiliki aktivitas antibakteri, antioksidan dan antipoliferatif (Sulaiman et al., 2006).

Sabun cair adalah sediaan berbentuk cair yang ditujukan untuk membersihkan kulit, dibuat dari bahan dasar sabun yang ditambahkan surfaktan, pengawet, penstabil busa, pewangi dan pewarna yang diperbolehkan dan dapat digunakan untuk mandi tanpa menimbulkan iritasi pada kulit (SNI, 1996).

\section{METODOLOGI PENELITIAN}

Waktu dan Tempat Penelitian

Penelitian ini dilaksanakan pada bulan Juli 2019 - September 2019 di Laboratorium Penelitian Farmasi Lanjut dan Laboratorium Biologi Dasar, Fakultas Matematika dan Ilmu Pengetahuan Alam, Universitas Sam Ratulangi, Manado.

\section{Bentuk Penelitian}

Bentuk Penelitian ini menggunakan metode eksperimental untuk formulasi sediaan sabun cair dari ekstrak daun Kersen dan pengujian efektivitas antibakteri dari ekstrak daun Kersen terhadap bakteri Staphylococcus epidermidis.

\section{Alat dan Bahan}

Alat

Alat yang digunakan dalam penelitian ialah $\mathrm{pH}$ meter $\left(\mathrm{ATC}^{\circledR}\right)$, gelas ukur $\left(\right.$ pyrex $^{\circledR}$ Iwaki), batang pengaduk, pipet tetes, erlenmeyer (pyrex ${ }^{\circledR}$ Iwaki), timbangan analitik (BB Adam), labu takar (pyrex ${ }^{\circledR}$ Iwaki), cawan petri, incubator (Ecocell MMM Group), autoklaf (ALP), oven, blender(Philips), beker gelas (pyre ${ }^{\circledR}$ Iwaki), penangas, piknometer (pyrex ${ }^{\circledR}$ Iwaki), jarum ose, pinset, mikropipet (Eco pipette CAPP), jangka sorong dan ayakan.

\section{Bahan}

Ekstrak etanol daun Kersen, isolat bakteri staphylococcus epidermidis, nutrient agar, minyak zaitun, Kalium Hidroksida $(\mathrm{KOH})$, Natrium Carboksil Metil Celulosa ( $\mathrm{Na}$ CMC), Sodium Lauryl Sulfate (SLS), asam stearat, Butyl Hidroksi Anisol (BHA), indikator fenolftalein, alkohol 96\%, sabun detol, HCL $0,1 \mathrm{~N}$, aluminium foil dan bakteri Staphylococcus epidermidis. 
PHARMACONJurnal Ilmiah Farmasi - UNSRAT Vol. 9 No. 1 FEBRUARI 2020 ISSN 2302 - 2493

Prosedur Penelitian

\section{Pengambilan Sampel}

Pengambilan sampel di Kelurahan Kleak, kecamatan Malalayang, Kota Manado. Bahan yang digunakan ialah bagian daun Kersen

\section{Identifikasi Sampel}

Identifikasi tanaman dilakukan di Laboratorium Taksonomi Tumbuhan, Jurusan Biologi, Fakultas Matematika dan Ilmu Pengetahuan Alam, Universitas Sam Ratulangi Manado.

\section{Ekstraksi}

Pembuatan ekstrak etanol daun Kersen menggunakan metode maserasi. Serbuk Daun Kersen ditimbang sebanyak $450 \mathrm{~g}$ dimasukkan dalam wadah, ditambahkan pelarut etanol $96 \%$ sebanyak $1600 \mathrm{~mL}$ didiamkan selama 3 hari sambil sesekali diaduk. Setelah 3 hari disaring dengan menggunakan kertas saring dan menghasilkan filtrat 1 dan debris 1 . Debris 1 yang ada kemudian direndam lagi (remaserasi) dengan pelarut yang sama selama 2 hari sambil sesekali diaduk. Setelah 2 hari, sampel disaring sehingga menghasilkan filtrat 2 dan debris 2 . Filtrat 1 dan filtrat 2 dicampurkan menjadi satu lalu dievaporasi menggunakan oven pada suhu $40^{\circ} \mathrm{C}$ sehingga diperoleh ekstrak kental. Selanjutnya ekstrak kental dikerok dan di masukkan kedalam wadah dan di timbang.

\section{Formula Sediaan Sabun Cair}

Formulasi sediaan sabun cair ekstrak etanol daun Kersen dapat dilihat pada Tabel. 1.
Tabel 1. Formula Sediaan Sabun Cair

\begin{tabular}{ccccc}
\hline Bahan & Satuan & \multicolumn{3}{c}{ Formula } \\
\hline Ekstrak Kersen & $\%$ & 10 & 15 & 20 \\
& & & & \\
KOH & $\%$ & 16 & 16 & 16 \\
Minyak zaitun & $\%$ & 30 & 30 & 30 \\
CMC & $\%$ & 1 & 1 & 1 \\
SLS & $\%$ & 1 & 1 & 1 \\
Asam stearat & $\%$ & 0,5 & 0,5 & 0,5 \\
BHA & $\%$ & 1 & 1 & 1 \\
Aquadest & $\mathrm{mL}$ & $\mathrm{ad}$ & $\mathrm{ad}$ & $\mathrm{ad}$ \\
& & 50 & 50 & 50 \\
& & $\mathrm{~mL}$ & $\mathrm{~mL}$ & $\mathrm{~mL}$ \\
\hline
\end{tabular}

\section{Pembuatan Sabun Cair Ekstrak Etanol Daun Kersen}

Semua bahan yang akan digunakan dihitung dan ditimbang terlebih dahulu sesuai dengan takaran yang dianjurkan. Dimasukkan minyak zaitun sebanyak $15 \mathrm{~mL}$ ke dalam gelas kimia, kemudian ditambahkan dengan kalium hidroksida $16 \%$ sebanyak $8 \mathrm{~mL}$ sedikit demi sedikit sambil terus dipanaskan pada suhu 50 ${ }^{\circ} \mathrm{C}$ hingga mendapatkan sabun pasta. Sabun pasta ditambahkan dengan $15 \mathrm{~mL}$ aquades, lalu dimasukkan Na-CMC yang telah dikembangkan dalam aquades panas, diaduk hingga homogen. Kemudian ditambahkan asam stearat, diaduk hingga homogen. Ditambahkan SLS, diaduk hingga homogen. Ditambahkan BHA, lalu diaduk hingga homogen. Dimasukkan ekstrak daun Kersen, diaduk hingga homogen. Sabun cair ditambahkan dengan aquades hingga volume $50 \mathrm{ml}$, dimasukkan ke dalam wadah bersih yang telah disiapkan. Pembuatan sabun cair ekstrak etanol daun Kersen disesuaikan dengan masingmasing konsentrasi.

\section{Uji Mutu Sediaan Sabun Cair Uji Organoleptik}

Sediaan yang sudah diformulasikan kemudian dilakukan pengamatan penampilan 
menggunakan pancaindera meliputi bau, warna dan bentuk sediaan (Muthmainnah et al., 2014).

\section{Uji pH}

Sebanyak $1 \mathrm{~g}$ sabun yang akan diperiksa diencerkan dengan aquades sehingga $10 \mathrm{~mL}$. Dimasukkan $\mathrm{pH}$ meter yang telah dikalibrasi ke dalam larutan sabun yang telah dibuat, kemudian ditunggu hingga indikator $\mathrm{pH}$ meter stabil dengan menunjukkan nilai $\mathrm{pH}$ yang konstan (SNI, 1996).

\section{Uji Kadar air}

Penetapan kadar air dilakukan dengan metode gravimetri. Prosedur gravimetri, timbang $1 \mathrm{~g}$ sampel pada cawan petri yang telah diketahui bobotnya, panaskan pada lemari pengering pada suhu $105^{\circ} \mathrm{C}$ selama 2 jam sampai bobot tetap.

\section{Uji Tinggi busa}

Pengukuran dilakukan dengan metode sederhana, dengan $1 \mathrm{~g}$ sabun dimasukkan kedalam tabung berskala $10 \mathrm{ml}$ aquades dan kemudian di tutup. Dikocok selama 20 detik dan dihitung tinggi busa yang terbentuk.

\section{Uji Bobot jenis}

Piknometer dikeringkan dan ditimbang. Air dimasukkan ke dalam piknometer dan didiamkan pada suhu $25^{\circ} \mathrm{C}$ selama 10 menit. Piknometr diangkat dan ditimbang.

\section{Uji Alkali bebas}

Sampel sabun cair ditimbang sebanyak $5 \mathrm{~g}$, kemudian dimasukkan ke dalam gelas piala $250 \mathrm{~mL}$. Selanjutnya ditambahkan $100 \mathrm{~mL}$ alkohol 96\% dan beberapa tetes larutan indikator fenolftalein. Lalu dipanaskan di atas penangas selama 30 menit sampai mendidih. Bila larutan berwarna ungu kemudian dititrasi dengan larutan HCL 0,1 N sampai warna ungu tepat hilang.

\section{Uji Efektivitas Antibakteri}

Uji Efektivitas antibakteri terhadap sabun cair ekstrak etanol Kersen menggunakan bakteri Staphylococcus epidermidis dengan cara difusi agar. 3 sumuran untuk setiap konsentrasi Sabun cair ekstrak etanol Kersen $10 \%, 15 \% 20 \%$ dan dua sumuran lain untuk kontrol positif (sabun Detol) dan kontrol negatif (Basis sabun cair ). Masing-masing sabun cair diambil $50 \mu \mathrm{L}$ dan dimasukkan pada setiap sumuran kemudian diinkubasi pada suhu $37^{\circ} \mathrm{C}$ selama $24 \mathrm{jam}$.

\section{HASIL DAN PEMBAHASAN}

Uji organoleptik dilakukan untuk melihat bentuk, warna, dan bau dari sediaan sabun cair. Hasil yang di dapat dari sediaan sabun cair dapat dilihat pada Tabel 2.

Tabel 2. Hasil Uji Organoleptik

\begin{tabular}{cccc}
\hline Sediaan & Bentuk & Bau & Warna \\
\hline Basis Sabun & Cair & Basis & Kuning \\
Konsentrasi & Cair & Ekstrak & Coklat \\
$10 \%$ & Cair & Ekstrak & Coklat tua \\
$\begin{array}{c}\text { Konsentrasi } \\
15 \%\end{array}$ & Cair & Ekstrak & Coklat tua \\
$\begin{array}{c}\text { Konsentrasi } \\
20 \%\end{array}$ & & & \\
\hline
\end{tabular}

Uji organoleptik bertujuan untuk melihat tampilan fisik suatu sediaan yang meliputi bentuk, warna dan bau. Standar yang ditetapkan SNI uji organoleptik sabun cair, bentuk yaitu cair, bau dan warna yaitu yang khas. Bentuk dari sabun cair yang dihasilkan pada penelitian ini yaitu cair, bau yang dihasilkan berbau khas daun Kersen. Sabun cair berwarna cokelat, warna cokelat pada sabun cair mengindikasikan adanya kandungan ekstrak etanol daun Kersen yang tampak berbeda dari basis sabun yaitu kuning. Berdasarkan hasil yang diperoleh, hasil pada penelitian ini sesuai dengan standar yang ditetapkan SNI. 
PHARMACONJurnal Ilmiah Farmasi - UNSRAT Vol. 9 No. 1 FEBRUARI 2020 ISSN 2302 - 2493

Uji $\mathrm{pH}$ dilakukan untuk mengetahui sediaan sabun cair yang dibuat sesuai dengan standar $\mathrm{pH}$ sabun yaitu 8-11. Hasil uji $\mathrm{pH}$ dapat dilihat pada Tabel 3 .

Tabel 3. Hasil Uji pH

\begin{tabular}{ccc}
\hline Sediaan & $\mathrm{pH}$ & Keterangan \\
\hline Basis Sabun & 9,3 & Memenuhi Syarat \\
Konsentrasi 10\% & 9,5 & Memenuhi Syarat \\
Konsentrasi 15\% & 9,1 & Memenuhi Syarat \\
Konsentrasi 20\% & 9,1 & Memenuhi Syarat \\
\hline
\end{tabular}

Uji pH merupakan salah satu syarat mutu sabun cair. Hal tersebut karena sabun cair kontak langsung dengan kulit dan dapat menimbulkan masalah apabila pH-nya tidak sesuai dengan $\mathrm{pH}$ kulit. Kulit memiliki kapasitas ketahanan dan dapat dengan cepat beradaptasi terhadap produk yang memiliki $\mathrm{pH}$ 8.0-10.8 Frost et al., (1982). Menurut SNI, untuk pH sabun cair diperbolehkan antara 8-11. Berdasarkan pengujian yang dilakukan, basis sabun cair memiliki pH 9,3, sabun cair konsentrasi $10 \%$ memiliki pH 9,5, konsentrasi $15 \% \quad 9,1$, konsentrasi $20 \% \quad 9,1$. Hasil menunjukan semua formula sabun cair yang dihasilkan memenuhi kriteria sabun cair yang baik.

Uji kadar air dilakukan untuk mengetahui presentase kandungan air dalm sabun cair. Menurut SNI, kadar air dalam sediaan sabun cair maksimal 60\%. Hasil uji kadar air dapat dilihat pada Tabel 4.

Tabel 4. Hasil Uji Kadar Air

\begin{tabular}{|c|c|c|}
\hline Sediaan & Kadar Air & Keterangan \\
\hline Basis Sabun & $47,6648 \%$ & $\begin{array}{c}\text { Memenuhi } \\
\text { Syarat }\end{array}$ \\
\hline Konsentrasi $10 \%$ & $60,6102 \%$ & $\begin{array}{c}\text { Memenuhi } \\
\text { Syarat }\end{array}$ \\
\hline Konsentrasi $15 \%$ & $55,2547 \%$ & $\begin{array}{c}\text { Memenuhi } \\
\text { Syarat }\end{array}$ \\
\hline Konsentrasi $20 \%$ & $49,8859 \%$ & $\begin{array}{c}\text { Memenuhi } \\
\text { Syarat }\end{array}$ \\
\hline
\end{tabular}

Uji kadar air dilakukan untuk mengetahui presentase kandungan air yang terdapat pada masing-masing sediaan sabun cair. Standar kadar air yang ditetapkan oleh SNI yaitu maksimal 60\%. Kadar air yang didapatkan dari masing-masing sediaan yaitu untuk basis sabun 47,6\%, sabun cair konsentrasi $10 \%$ kadar air yang diperoleh $60,6 \%$, konsentrasi $15 \%$ kadar air yang diperoleh 55,2\%, konsentrasi $20 \%$ kadar air yang diperoleh $49,8 \%$. Dari hasil yang diperoleh semua konsentrasi memenuhi standard yang ditetapkan SNI. Berdasarkan pengujian kadar air yang diperoleh, semakin besar konsentrasi ekstrak yang di tambahkan maka semakin kecil presentase kadar air yang didapatkan. Kadar air yang lebih tinggi ini berasal dari bahan-bahan yang bersifat higroskopis yaitu seperti SLS dan CMC.

Uji tinggi busa dilakukan untuk melihat daya busa yang dihasilkan sabun cair yang dibuat sesuai dengan standar tinggi busa sabun yang ditetapkan oleh Standar Nasional Indonesia (SNI) yaitu 13-220 mm. Hasil uji tinggi busa dapat dilihat pada Tabel 5 .

Tabel 5. Hasil Uji Tinggi Busa

\begin{tabular}{|c|c|c|}
\hline Sediaan & Tinggi Busa (mm) & Keterangan \\
\hline Basis Sabun & 76 & $\begin{array}{l}\text { Memenuhi } \\
\text { Syarat }\end{array}$ \\
\hline Konsentrasi $10 \%$ & 85 & $\begin{array}{l}\text { Memenuhi } \\
\text { Syarat }\end{array}$ \\
\hline Konsentrasi 15\% & 70 & $\begin{array}{l}\text { Memenuhi } \\
\text { Syarat }\end{array}$ \\
\hline Konsentrasi $20 \%$ & 71 & $\begin{array}{c}\text { Memenuhi } \\
\text { Syarat }\end{array}$ \\
\hline
\end{tabular}

Berdasarkan SNI, syarat tinggi busa dari sabun cair yaitu 13-220 mm. Dari hasil pengamatan tinggi bus didapat basis sabun cair $76 \mathrm{~mm}$, sabun cair konsentrasi 10\% tinggi busa yang didapat $85 \mathrm{~mm}$, konsentrasi $15 \%$ tinggi busa yang didapat $72 \mathrm{~mm}$, konsentrasi $20 \%$ tinggi busa yang didapat $71 \mathrm{~mm}$. Dari hasil tersebut dapat dilihat bahwa semakin tinggi 
PHARMACONJurnal Ilmiah Farmasi - UNSRAT Vol. 9 No. 1 FEBRUARI 2020 ISSN 2302 - 2493

konsentrsi sabun cair maka semakin sedikit busa yang dihasilkan. Menurut Schramm (2005), stabilitas busa dipengaruhi oleh konsentrasi dan viskositas sediaan. Dari hasil yang diperoleh, semua konsentrasi memenuhi standar sabun yang sesuai dengan SNI.

Uji bobot jenis dilakukan untuk mengetahui bobot jenis dari sabun cair. Bobot jenis dari suatu sediaan sabun cair menurut SNI adalah 1,01-1,1 $\mathrm{g} / \mathrm{mL}$. hasil uji bobot jenis dapat dilihat pada Tabel 6 .

Tabel 6. Hasil Uji Bobot Jenis

\begin{tabular}{ccc}
\hline Sediaan & Bobot jenis $(\mathrm{g} / \mathrm{ml})$ & Keterangan \\
\hline Basis Sabun & 1,0745 & Memenuhi Syarat \\
Konsentrasi & 1,1035 & Memenuhi Syarat \\
$10 \%$ & & Memenuhi Syarat \\
$\begin{array}{c}\text { Konsentrasi } \\
15 \%\end{array}$ & 1,1176 & Memenuhi Syarat \\
$\begin{array}{c}\text { Konsentrasi } \\
20 \%\end{array}$ & 1,1482 & \\
\hline
\end{tabular}

Nilai bobot jenis dipengaruhi suatu bahan dipengaruhi penyusunnya dan sifat fisiknya. Uji bobot jenis bertujuan untuk mengetahui kekentalan sabun cair. Berdasarkan SNI, standar bobot jenis pada sabun cair yaitu 1,01-1,1 g/ml. Pengujian bobot jenis menggunakan alat piknometer, dari hasil pengamatan diperoleh bobot jenis dari basis sabun ialah $1,074 \mathrm{~g} / \mathrm{ml}$, bobot jenis konsentrasi $10 \%$ ialah $1,103 \mathrm{~g} / \mathrm{ml}$, bobot jenis konsentrasi $15 \%$ ialah $1,117 \mathrm{~g} / \mathrm{ml}$, bobot jenis konsentrasi $20 \%$ ialah 1,148 g/ml. Berdasarkan hasil yang diperoleh dapat dilihat bahwa bobot jenis konsentrasi $15 \%$ dan $20 \%$ tidak memenuhi syarat sabun sesuai dengan SNI.

Uji alkali bebas dilakukan untuk mengetahui ada tidaknya alkali bebas pada sabun cair. Menurut SNI, alkali bebas dalam suatu sediaan sabun cair maksimal $0,1 \%$. Hasil uji alkali bebas dapat dilihat pada Tabel 7 .
Tabel 7. Hasil Uji Alkali Bebas

\begin{tabular}{|c|c|c|}
\hline Sediaan & Alkali bebas & Keterangan \\
\hline Basis Sabun & $0,017 \%$ & $\begin{array}{l}\text { Memenuhi } \\
\text { Syarat }\end{array}$ \\
\hline Konsentrasi $10 \%$ & $0,017 \%$ & $\begin{array}{l}\text { Memenuhi } \\
\text { Syarat }\end{array}$ \\
\hline Konsentrasi 15\% & $0,017 \%$ & $\begin{array}{l}\text { Memenuhi } \\
\text { Syarat }\end{array}$ \\
\hline Konsentrasi $20 \%$ & $0,017 \%$ & $\begin{array}{c}\text { Memenuhi } \\
\text { Syarat }\end{array}$ \\
\hline
\end{tabular}

Uji kadar alkali bebas untuk melihat jumlah basa yang tidak terikat oleh asam lemak. Kadar alkali bebas yang didapat dari masing-masing konsentrasi sabun cair yaitu $0,017 \%$. Berdasarkan SNI, standar alkali bebas pada sabun cair yaitu maksimal $0,1 \%$. Hal ini menunjukan bahwa sabun cair ekstrak etanol daun Kersen terbukti sesuai dengan standar yang ditetapkan oleh SNI. Kurangnya kandungan alkali bebas yang terdapat dalam sabun cair, ini disebabkan karena pada pembuatan basis sabun cair dilakukan pemanasan yang lama hingga sabun menjadi pasta sehingga kalium hidroksida yang merupakan salah satu pembentukan basis sabun sudah bereaksi dengan lemak atau minyak zaitun.

Hasil yang didapat dari uji efektivitas antibakteri sabun cair ekstrak daun Kersen melalui pengamatan selama 1 hari dengan masa inkubasi 24 jam dan dengan 3 kali perlakuan untuk masing-masing sediaan sabun cair. Hasil ini telah dikurangi diameter sumuran dapat dilihat pada Tabel 8 . 
PHARMACONJurnal Ilmiah Farmasi - UNSRAT Vol. 9 No. 1 FEBRUARI 2020 ISSN 2302 - 2493

Tabel 8. Uji Antibakteri staphylococcus

epidermidis sabun cair ekstrak etanol daun kersen.

\begin{tabular}{|c|c|c|c|c|c|}
\hline \multirow[t]{2}{*}{ Sediaan } & \multicolumn{4}{|c|}{$\begin{array}{l}\text { Hasil Pengukuran diameter } \\
\text { zona hambat }(\mathrm{mm})\end{array}$} & \multirow[t]{2}{*}{ Keterangan } \\
\hline & $\mathrm{p} 1$ & P2 & P3 & $\begin{array}{l}\text { Rata- } \\
\text { rata }\end{array}$ & \\
\hline $\begin{array}{l}\text { Konsentra } \\
\text { si } 10 \%\end{array}$ & 0,5 & 0,5 & 0,5 & 0,5 & Lemah \\
\hline $\begin{array}{l}\text { Konsentra } \\
\text { si } 15 \%\end{array}$ & 1 & 1 & 1 & 1 & Lemah \\
\hline $\begin{array}{c}\text { Konsentra } \\
\text { si } 20 \%\end{array}$ & 1,5 & 2,5 & 0,5 & 1,5 & Lemah \\
\hline Kontrol + & 2,5 & 5 & 3,5 & 3,6 & Lemah \\
\hline Kontrol - & 0 & 0 & 0 & 0 & Lemah \\
\hline
\end{tabular}

Uji efektivitas antibakteri sabun cair ekstrak etanol daun Kersen pada bakteri Staphylococcus epidermidis menggunakan metode difusi. Metode ini digunakan karena kesederhanaan teknik dan ketelitian, selain itu metode ini sering digunakan untuk pengujian kepekaan antibiotik. Metode ini melihat kepekaan bakteri terhadap antibiotik atau bahan yang berpotensi sebagai antibakteri yang ditandai dengan terbentuknya zona hambatan (daerah bening) disekitar sumur. Hasil uji efektivitas antibakteri sabun cair ekstrak etanol daun Kersen dengan konsentrasi 10\%, 15\% dan $20 \%$ di kategorikan lemah. Dalam penelitian ini setiap konsentrasi memiliki zona hambat yang lemah. Madigan et al,( 2005), menyatakan bahwa terbentuknya zona hambat sangat tergantung oleh jumlah bahan antibakteri yang diteteskan ke cakram, daya larut antibakteri tersebut ke media, koefisien difusi, dan efektivitas antibakteri tersebut. Dari hasil penelitian tersebut hasil efektivitas antibakteri ketiga konsentrasi sabun cair ekstrak etanol daun Kersen memberikan zona hambat yang kecil dari pada kontrol positif (Detol) pada bakteri staphylococcus epidermidis.

\section{KESIMPULAN}

Berdasarkan hasil penelitian maka dapat disimpulkan bahwa :

1. Ekstrak etanol daun Kersen dapat diformulasikan menjadi sabun cair dengan konsentrasi $10 \%, 15 \%$ dan 20\%. Hasil pengujian mutu sabun cair ekstrak etanol daun Kersen konsentrasi 10\% memenuhi persyaratan sesuai dengan standar yang ditetapkan SNI ialah uji organoleptik, uji $\mathrm{pH}$, uji tinggi busa, uji kadar air, uji alkali bebas, uji bobot jenis. Konsentrasi $15 \%$ dan $20 \%$ tidak memenuhi standar uji bobot jenis.

2. Hasil uji efektivitas antibakteri sabun cair ekstrak etanol daun Kersen diperoleh memiliki efektivitas antibakteri terhadap bakteri Staphylococcus epidermidis masuk dalam kategori zona hambat lemah.

\section{SARAN}

Disarankan untuk penelitian berikutnya dilakukan pengujian antibakteri dengan metode dilusi dan menggunakan bakteri lain.

\section{DAFTAR PUSTAKA}

Dwidjoseputro, D., 1978. Dasar-dasar mikrobiologi. Djambatan, Jakarta.

Gardner, Gray, O'rahilly, 1995. Anatomi. Penerbit Universitas Indonesia, Jakarta.

Madigan, M.T., Martinko, J., 2005. Brock Biology of Microorganisms, 11th edn. SciELO Espana.

Muthmainnah, R., Rubiyanto, D., Julianto, T.S., 2014. Formulasi Sabun Cair Berbahan Aktif Minyak Kemangi Sebagai Antibakteri Dan Pengujian Terhadap Staphylococcus aureus. Indo Jurnal Chem Res 1, 44-50.

Schramm, L.L., 2006. Emulsions, foams, and suspensions: fundamentals and applications. John Wiley \& Sons. 
SNI, 1996. Standar Mutu Sabun Mandi

Cair. Dewan Standarisasi Nasional, jakarta.

Steenis, C.G.G.J., Hoed, G., Bloembergen, S., Eyma, P.J., Nur, N., 1967. Flora Untuk Sekolah Di Indonesia. Fakultas Biologi, Universitas Nasional.Churchill Livingstone, London.

Sulaiman, Z.M., Somchit, Z.M., Thenamutha, M., Kasthuri, D., 2006. The in vitro antibacterial activity of Muntingia calabura extracts. Jurnal Pharmacy 2, 439-4 